\title{
MANUFACTURING OF CAST-METAL SPONGES FROM COPPER ALLOYS
}

\author{
IZDELAVA LITIH KOVINSKIH GOBIC IZ ZLITIN NA OSNOVI \\ BAKRA
}

\author{
Václav Merta ${ }^{1 *}$, Ivo Lána ${ }^{2}$ \\ ${ }^{1}$ VSB - Technical University of Ostrava, 17. listopadu 2172/15, 70800 Ostrava - Poruba, Czech Republic \\ ${ }^{2}$ Slévárna a modelárna Nové Ransko, s.r.o., Nové Ransko 234, 58263 Ždírec nad Doubravou, Czech Republic \\ Prejem rokopisa - received: 2019-07-16; sprejem za objavo - accepted for publication: 2019-11-04
}

doi:10.17222/mit.2019.159

\begin{abstract}
The paper deals with the topic of manufacturing metal sponges from copper alloys using a special foundry technology of "a two-stage investment-casting process using an evaporative polyurethane (PUR) pattern". Particular attention is paid to the study of castability as a technological characteristic, which is a limiting factor for the production of such castings. The castability of the $\mathrm{CuSn} 12$ copper alloy was observed in various production-process conditions (pouring temperature, mould temperature) with the aim to find dependence trends and set the optimal conditions of the manufacturing process. From the results, it is obvious that the crucial factor influencing the castability is the mould temperature, although the pouring temperature also has a smallish influence on it.

Keywords: metal sponge, investment casting, castability
\end{abstract}

V članku avtorji opisujejo izdelavo kovinskih pen iz bakrovih zlitin z uporabo posebne livarske tehnologije t.i. dvostopenjskega precizijskega litja, ki uporablja postopek izparevanja poliuretana (PUR). Posebno pozornost so avtorji posvetili študiju livnosti, ki kot tehnološka lastnost omejuje izdelavo takšnih ulitkov. Livnost bakrove zlitine CuSn12 so opazovali pri različnih procesnih pogojih (temperaturi litja, temperaturi modela oz. forme) z namenom, da bi ugotovili odvisnostne tendence in ugotovili optimalne pogoje proizvodnega postopka. Iz rezultatov opazovanj oz. preizkusov je očitno, da je temperatura modela odločilen faktor, ki vpliva na livnost, čeprav ima nanjo določen vendar relativno majhen vpliv tudi temperatura litja.

Ključne besede: kovinske gobice (pene), precizijsko litje, livnost

\section{INTRODUCTION}

The paper deals with the possibilities of producing metal foams using conventional foundry processes and technologies. Particular attention is paid to the "twostage investment-casting process using an evaporative polyurethane (PUR) pattern". This method produces a porous metallic material, which is usually called a "metal sponge". These metal sponges excel the other types of metal foams due to a high porosity (up to $97 \%$ ) and especially because the pores are open and fully interconnected. A metal sponge is therefore a material with a wide range of applications in functional components such as filters, heat exchangers or catalyst carriers. ${ }^{1}$

One of the most important tasks in the production of these thin-walled castings with a very complex structure is to achieve sufficient castability. This is typically achieved with relatively specific process conditions such as the use of a reduced or elevated pressure (or a combination of both) and relatively high pouring temperatures and mould temperatures. Although these conditions are advantageous in terms of the required castability, they have a relatively unfavourable effect on the solidification process. A previous research showed

*Corresponding author's e-mail: vaclav.merta@vsb.cz (Václav Merta) that it is crucial to set the conditions of the manufacturing process (pouring temperature, mould temperature) very precisely to achieve the optimal castability. At low temperatures, misrun defects occur and a number of defects adversely affecting the mechanical and utility properties of these castings occur in the case of overheating. It is therefore necessary to find a suitable compromise for each cast material to obtain high-quality castings. $^{2}$

\section{EXPERIMENTAL PART}

The principle of the two-stage investment-casting manufacturing method is to embed a pattern of polymer foam into a suitable refractory material, followed by drying and annealing of the mould. During the annealing, the foam pattern evaporates. This forms a cavity, into which molten metal is subsequently cast. After the removal of the refractory material, a cast metal foam is obtained, which is an exact copy of the foam pattern. ${ }^{3}$

In order to optimize the manufacturing conditions, the castability of the CuSn12 copper alloy was monitored in the conditions of the cast-metal-sponge production. The experiment was carried out on a special Indutherm MC15 casting machine. This allows melting and casting under a vacuum (20 mbar), while the solidifi- 


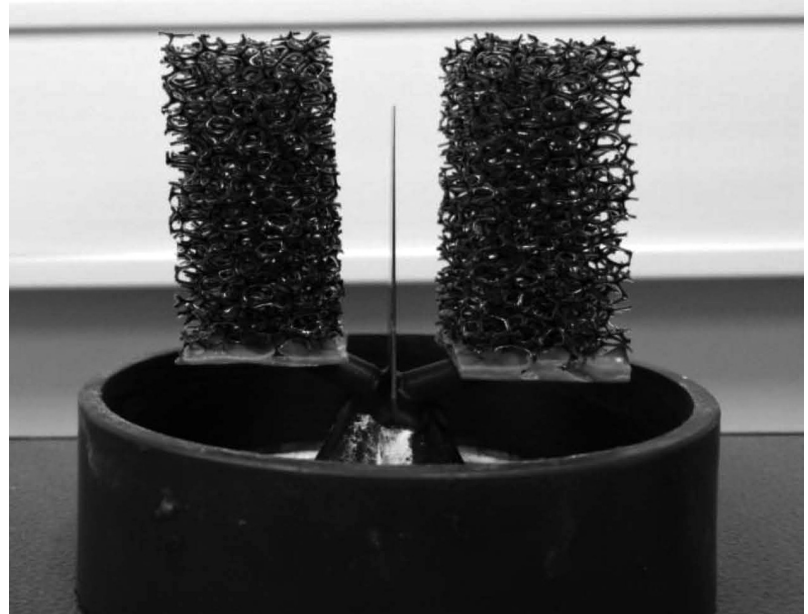

Figure 1: Test-casting pattern

cation is carried out under a super-atmospheric pressure (2 bar). Reticulated polyurethane foam Bulpren S 32450 (Eurofoam TP, s.r.o., CZ) with a 10-ppi porosity was used as the pattern and a special plaster composite, Eurovest (SRS Ltd., GB), was used as the moulding material. The test casting itself was designed as a pair of equal pieces made of foam $(40 \times 30 \times 20 \mathrm{~mm})$ and a $\varnothing 5$-mm sprue in a $1-\mathrm{mm} \mathrm{wall}{ }^{4}(30 \times 20 \mathrm{~mm})$. Figure 1 shows the pattern ready for being embedded in plaster.

\section{RESULTS}

Since the foam samples used for test casting are not precisely quantifiable (due to their irregular structures), the experiment could only be evaluated qualitatively. The evaluation was carried out on the basis of whether the test mould was fully filled or not. An example of fully realised test casting obtained after cleaning is presented in Figure 2. The combinations of the mould temperature and the lowest appropriate pouring temperature required to achieve a full filling of the mould were then con-

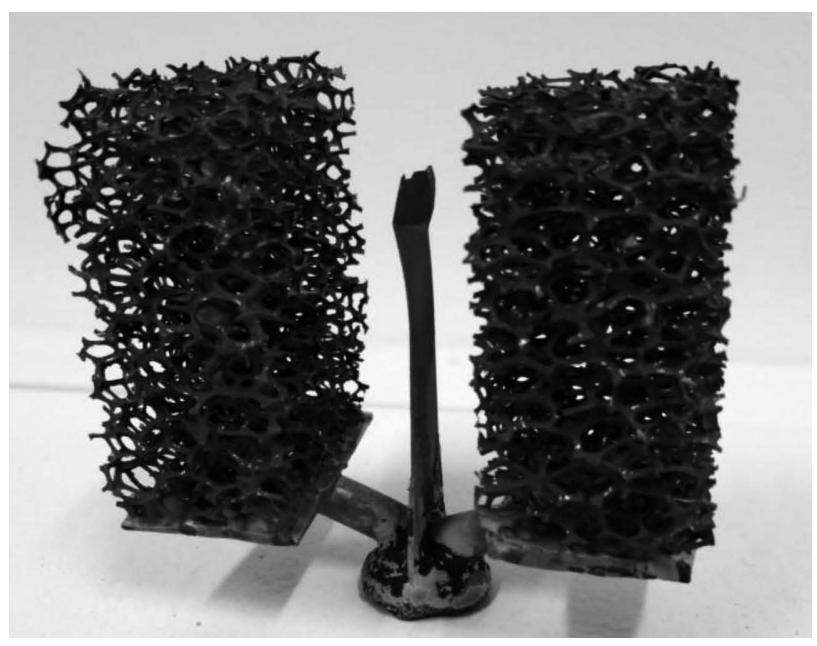

Figure 2: Resulting test casting
CuSn12 castability according to mould and pouring temperature

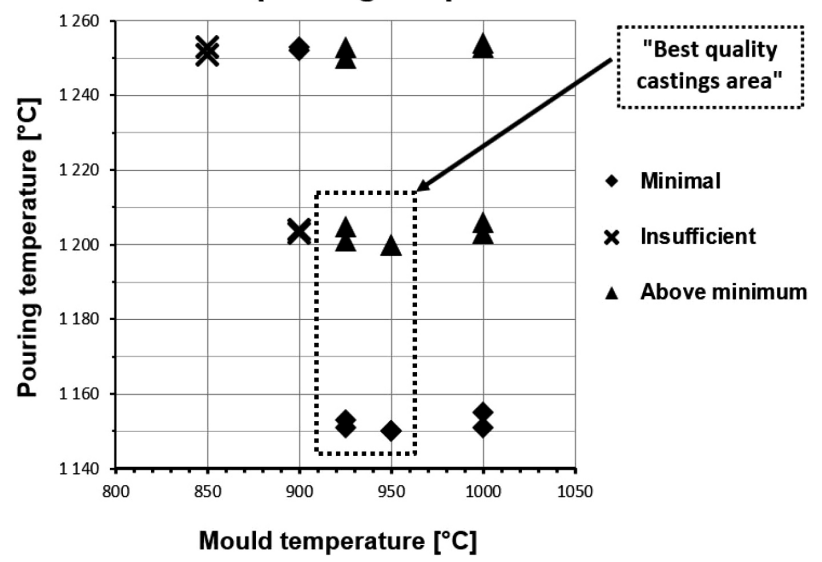

Figure 3: Results for the castability of CuSn12 according to the mould and pouring temperature

sidered to be the optimized process conditions sought. It was observed that the suitable conditions (in terms of castability) for the production of cast $\mathrm{CuSn} 12$ sponges are pouring temperatures of $1150-1250{ }^{\circ} \mathrm{C}$ and mould temperatures of $900-1000{ }^{\circ} \mathrm{C}$. However, the best results were achieved with pouring temperatures of $1150-1200{ }^{\circ} \mathrm{C}$ and mould temperatures of $925-950{ }^{\circ} \mathrm{C}$. The results of the experiment are graphically illustrated in Figure 3.

\section{DISCUSSION}

Based on the results, the influence of the pouring temperature and the initial mould temperature on the resulting castability were evaluated in order to determine the optimized conditions for the casting process. However, due to the very specific conditions of the process (the pressure conditions during the casting and solidification, an irregular structure of the pattern), it is difficult to evaluate the results of the experiment on the basis of a full reproducibility. It is also necessary to realize that the optimized conditions are valid for achieving a full occupancy for a given sample size. It is therefore necessary to take the achieved results only as guidelines for further research.

According to the graph in Figure 3, there can be a dependence between the two parameters. As the mould temperature rises, the pouring temperature required for a full filling of the mould decreases and vice versa. In addition, it is clear that in the observed area, the influence of the mould temperature on the castability is much stronger than that of the pouring temperature.

\section{CONCLUSIONS}

A series of test castings was realised to monitor the influence of both the pouring temperature and the mould temperature on the castability of $\mathrm{CuSn} 12$ in laboratory 
conditions of an investment-casting metal-sponge production. The obtained results show that for the production of castings of the required quality, the optimized values of the monitored parameters are found in the following intervals: a casting temperature of $1150-1200{ }^{\circ} \mathrm{C}$ and a mould temperature of $925-950{ }^{\circ} \mathrm{C}$.

\section{Acknowledgment}

The contribution was carried out with the support of The Ministry of Education, Youth and Sports of the Czech Republic - CZ.02.1.01/0.0/0.0/17_049/0008399, the Technology Agency of the Czech Republic TH02020668 and projects of "Student Grant Competition", numbers SP2020/39 and SP2020/64.

\section{REFERENCES}

${ }^{1}$ J. Banhart, Manufacture, characterisation and application of cellular metals and metal foams, Progress in Materials Science, 46 (2001) 6, 559-632, doi:10.1016/S0079-6425(00)00002-5

${ }^{2}$ L. Wang, H. Li, F. Wang, J. Ren, Preparation of the open pore aluminum foams using investment casting process, Acta Metallurgica Sinica (English Letters), 14 (2001) 1, 27-32

${ }^{3}$ I. Kroupová, P. Lichý, F. Radkovský, J. Beňo, V. Bednářová, I. Lána, Optimization of the annealing of plaster moulds for the manufacture of metallic foams with an irregular cell structure, Mater. Tehnol., 49 (2015) 4, 527-530, doi:10.17222/mit.2014

${ }^{4}$ I. Kroupová, P. Lichý, L. Ličev, J. Hendrych, K. Souček, Evaluation of Properties of Cast Metal Foams with Irregular Inner Structure, Archives of Metallurgy and Materials, 63 (2018) 4, 1845-1849 